\title{
CHROMOSOME NUMBERS AND SEEDLING MORPHOLOGY OF SOME ANGIOSPERMAE COLLECTED IN BRAZIL*
}

\author{
TH. W. J. GADELLA, E. KLIPHUIS, J. C. LINDEMAN and E. A. MENNEGA
}

Botanisch Museum en Herbarium, Utrecht

\section{SUMMARY}

The chromosome numbers of 31 species of Angiospermae collected in S. Brazil were determined. Of these species 5 were studied before, the other numbers are new, 11 are first counts for genera and one even for a family. Some notes on the cytology and morphology are added.

\section{INTRODUCTION}

Up till now relatively little work has been done on the cytology of South American plants. The following authors published some data on chromosome numbers of South American species: Argentina: BöCHER c.s. (1963); CovaS (1949); Covas \& Hunziker (1954); Covas \& SCHNACK (1947); RAHN (1960); SCHNACK \& Covas (1947); Chile: DE Tschischow (1956); Colombia: Shibata (1962); Ecuador: HeISER (1963); Peru: Diers (1961); HuYnh (1965); Suriname: GaDella \& KLIPHUIS (1964). Besides these documented lists of chromosome numbers also some incidental studies were carried out in various genera of Angiospermae, but in general the conclusion can be drawn that - especially in comparison with Europe, Japan and North America - much is still to be done in the field of cytology before a more satisfactory picture can be obtained.

With this situation in mind the third author started three years ago on a trip to Brazil accompanied by the advanced student $\mathbf{J}$. H. de Haas. The principal aim was to study the composition of the endangered primary forests in the southern state of Paraná. It soon became evident that fixation of roottips in the field could not be carried out in the already tight program. Therefore arrangements were made with the Botanical Museum at Utrecht, to make use of the plants grown from seed samples sent from Paraná for making roottip fixations. These samples were originally intended for enriching the assortment of the Botanical Garden.

\section{MATERIAL AND METHODS}

In general the plants that yielded mature fruits were at the same time collected to prepare herbarium specimens. Partially these were deposited in the Hatschbach Herbarium at Curitiba and in other Brazilian herbaria; the other part was

* Dedicated to Professor Dr. C. E. B. Bremekamp. 
sent to the Utrecht Herbarium from where duplicates will be distributed. Only when a well-known species had been collected already in the same region before or when a certain plant was in a state defying the preparation of a recognizable herbarium specimen, seeds were gathered without a voucher. From the fruits the seeds were shed or peeled and, if necessary, left to become air-dry in a shady place before being packed in small plastic bags to be sent by air to Utrecht. This was carried out in general within a few weeks. On arrival there the seeds were sown without delay and grown in the greenhouses of the University in the fourth author's care, who also identified the species as soon as they reached flowering state. In this way a germination percentage of about $70 \%$ was achieved.

After germination if possible 1 or 2 seedlings were used for the fixation of roottips. Subsequently these seedlings were dried as voucher-specimens which are the more valuable as only very little is known so far about the seedling morphology of tropical and subtropical plants.

In other instances roottips were fixed at a later stage when this could be done without damaging the plants. Of these plants a voucher-specimen could not yet be taken. In the past summer all four authors undertook a thorough check of all the plants with the multiple administration of the Brazilian material sent to Utrecht. Almost all the treated species and certainly the ones mentioned in this publication are still alive. Of a few annuals in the collection the greenhouse harbours already a second generation.

All 31 species mentioned in this paper were collected in the Brazilian state of Paraná and with the exception of no. 19 and 20, being fruit-trees originating from Asia, in natural vegetations. The parent plants in general bear numbers between 1 and 6.200 of the collection Lindeman and de Haas; those gathered on trips in combination with Mr. G. Hatschbach, specialist on the Paraná flora, were incorporated in his numbering well above 13.000. In those cases where no voucher of the parent plant was prepared, the garden number preceded by the year abbreviation is given as reference number.

For certain identifications we gratefully acknowledge the help of Mrs. Graziela Barroso (Brasília, Compositae), Mrs. Ida de Vattimo (Rio de Janeiro, Lauraceae) and Mr. L. Y. Th. Westra (Utrecht, Malvales). About half of the species, those which flowered already in the greenhouses, were identified by the fourth author, whereas the third author identified the remainder from herbarium specimens and checked all dried and living plants.

The first and second author took care of the fixation of the material and counted the chromosomes.

Many other species will be the subject of further studies and we hope to publish the results in later papers.

The roottips were fixed in Karpechenko, embedded in paraffin, and sectioned at 15 micron. The sections were stained according to the Heidenhain haematoxylin method.

The microscopical preparations are preserved in the cytotaxonomical division of the Botanical Museum and Herbarium of the Utrecht University. 
Table 1.

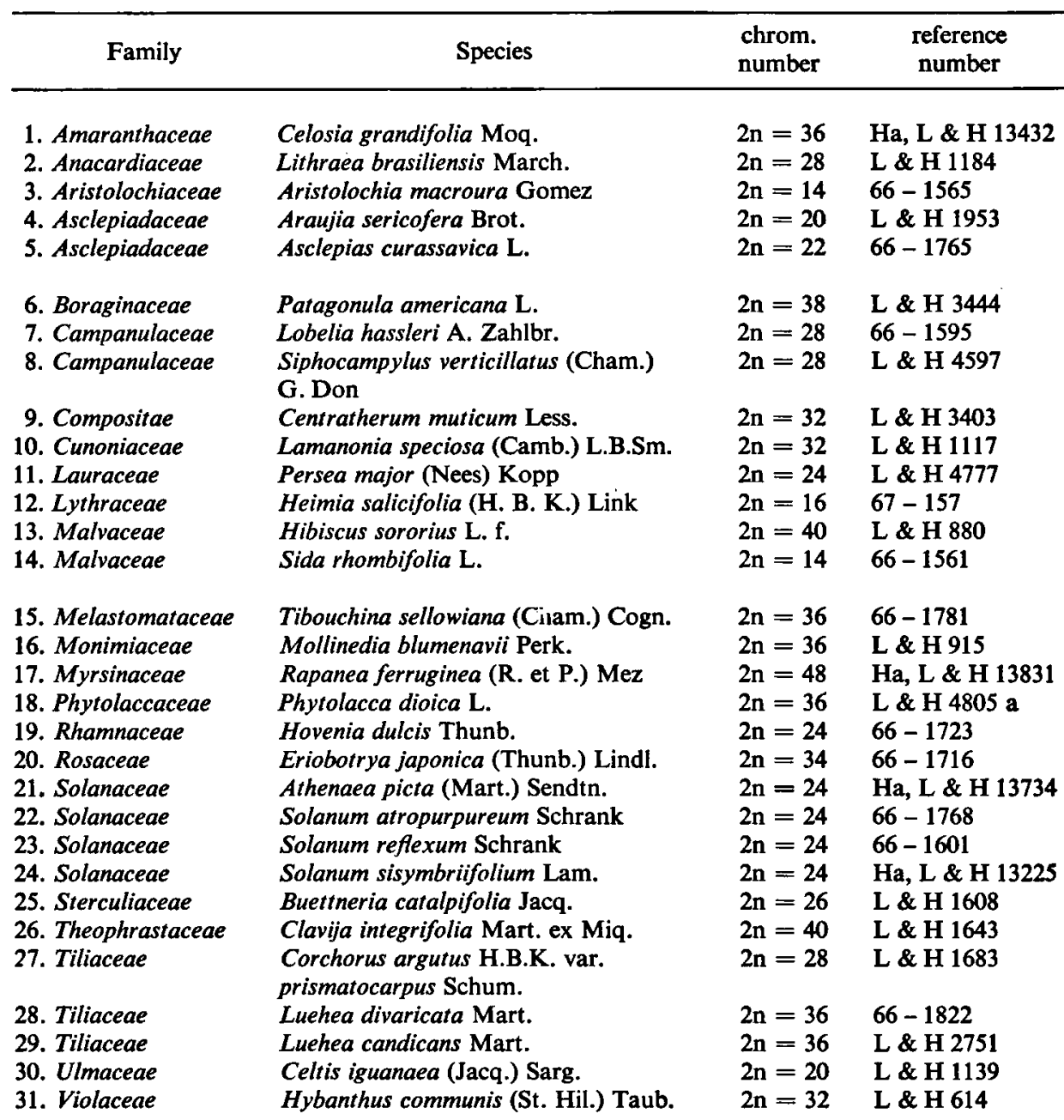

* $\mathrm{S}=$ seedling, fl. = flowering spec.

The sketches of seedlings were drawn by Mr. W. H. A. Hekking except for fig. 9 which was made by Mr. T. Schipper.

All data are assembled in table 1.

\section{SOME NOTES ON THE CHROMOSOME NUMBERS SHOWN IN THE TABLE}

The chromosome numbers for 7 of the species listed above were published before by other authors and our results are in agreement with these counts. The 


$\begin{array}{ccc}\begin{array}{c}\text { state of } \\ \text { voucher }\end{array} & \text { source } & \text { previous } \\ \text { results }\end{array}$

1. $S+$ fl. Serra do Mar Jan.

2. - campo margin S. Par. May

3. $\mathbf{S}+$ fl. campo margin S. Par. May

4. $\mathrm{S}+$ fl. grazed campo S. C. July

5. fl. roadside

6. S forest Iguaçu Park Nov.

7. $\mathrm{S}+\mathrm{fl}$. campo 1st planalto

8. fil. marsh n. Curitiba Febr.

9. fi. forest road Iguaçu Park Dec.

10. S campo margin S. Par. May

11. - forest S. Par. March

12. fl. marsh n. Curitiba

13. - margin of pond N. Par. April

14. $S$ roadside

15. S Serra do Mar

16. S forest Ivaí NW Par. April

17. S Araucaria forest S. Par. Febr.

18. - SW Par. March

$19 . \quad$ - garden Curitiba

20. S garden Curitiba

21. fi. marshy valley S. Par. Febr.

22. fi.

23. fl.

24. fi. roadside Central Par. Dec.

25. S forest n. Xambrê W. Par. June

26. $S$ forest $n$. Xambrê $\mathbf{W}$ Par. June

27. $\mathbf{S}+$ fl. levee R. Piquirí June

28. S forest Cêrro Azul NE Par. Aug.

29. S sec. wood R. Mourão NW Par. Oct.

30. $S$ forest $S$ Par. April

31. $\mathbf{S}+$ fl. bank R. Ivaí NW Par. March
$2 n=22$ Bezbaruah (1963), Diers (1961), Huynh (1965), Lewis (1961)
$2 \mathrm{n}=36$ Schnack \& Covas (1947)

$2 n=24$ Sugiura (1936)

$2 \mathrm{n}=24$ Gottschalk (1954)

$\mathrm{n}=12$ Heiser (1963)

other 24 species were studied cytologically for the first time. In several of the genera no chromosome counts had been made previously viz. in Lithraea, Araujia, Patagonula, Lamanonia, Mollinedia, Eriobotrya, Athenaea, Buettneria, Luehea, and Clavija, the last representing also the first count of an identified species in the family Theophrastaceae.

In other genera our results agree completely with counts carried out with other species, but in some cases apparently more than one basic number is present in the same genus. 
1. In Celosia the basic number $\mathrm{x}=9$ has been deduced from species with $2 n=36,54$ and 72 .

3. In Aristolochia most species have $2 \mathrm{n}=14$ and $2 \mathrm{n}=28$.

5. Asclepias has the basic number $\mathrm{x}=11$.

7, 8. Lobelia and Siphocampylus both have $\mathrm{x}=7$.

9. In Centratherum only one Asiatic species had been studied before. For C. rangacharii Gamble $\mathrm{n}=9$ was determined by SHETTY (1967) in material from Kerala, India. In $C$. muticum Less. the number $2 \mathrm{n}=32$ appeared, indicating that more than one basic number exists in this genus.

13. In Hibiscus various basic numbers do occur, but one set of species is characterized by the basic number $x=20$.

15. For Tibouchina brevisepala (Cham.) Cogn. HuYNH (1965) counted $2 n=18$. The species $T$. sellowiana (Cham.) Cogn. for which we here report $2 n=36$ may be considered to be tetraploid.

17. In Rapanea only one unidentified species from New Guinea was counted by Borgmann as $2 n=48$, a number which corresponds with that of the South American $R$. ferruginea (R. et P.) Mez.

22 , 24. In Solanum most species appear to have the number $2 \mathrm{n}=24$.

26. In Clavija only a count of an unidentified species without known origin has been published by S. \& G. MANGENOT (1962). They give the provisional number $2 n=36$ r. Noe $2 n=40$ was found for $C$. integrifolia Mart. ex Miq. and the remark can be made that in this species the chromosomes are very different in size with some small ones present.

27. For Corchorus $\mathrm{x}=7$ has been established already.

30. In Celtis some species were already known with $2 \mathrm{n}=20$, whereas in other species the basic numbers $\mathrm{x}=11,13$ and 14 have been found.

31. In Hybanthus only the African $H$. enneaspermus (L.) v. Muell. had been investigated by S. \& G. MANGenot (1962), who found there $2 n=32$ as well, in another section.

\section{NOTES ON MORPHOLOGICAL AND OTHER ASPECTS OF SOME SPECIES}

1. Celosia grandiflora starts to form a pseudo-rosette with leaves rather different in shape from the cauline leaves seen in older plants (fig. 7). Even the dried seedling shows a definite reddish colouring of cotyledons and first leaves encountered rather often in shade-loving species.

3. Seeds of Aristolochia macroura were gathered from a shower of already opened fruits on leafless shoots and for the fixation incidentally a remarkable siamese twin turned out to be used (fig. 9). This specimen has an apparently normal hypocotyl but directly above the petioles and alternating with them stands a whorl of 2 somewhat unequal pairs of pseudo-cotyledons. From their centre spring 2 healthy and at the base equally strong shoots in a plane perpendicular to that of the cotyledons. All leaves of the 20 respectively $40 \mathrm{~cm}$ long shoots have small laterally flattened axillar buds. Only at a later stage such buds start to develop simultaneously with the un- 


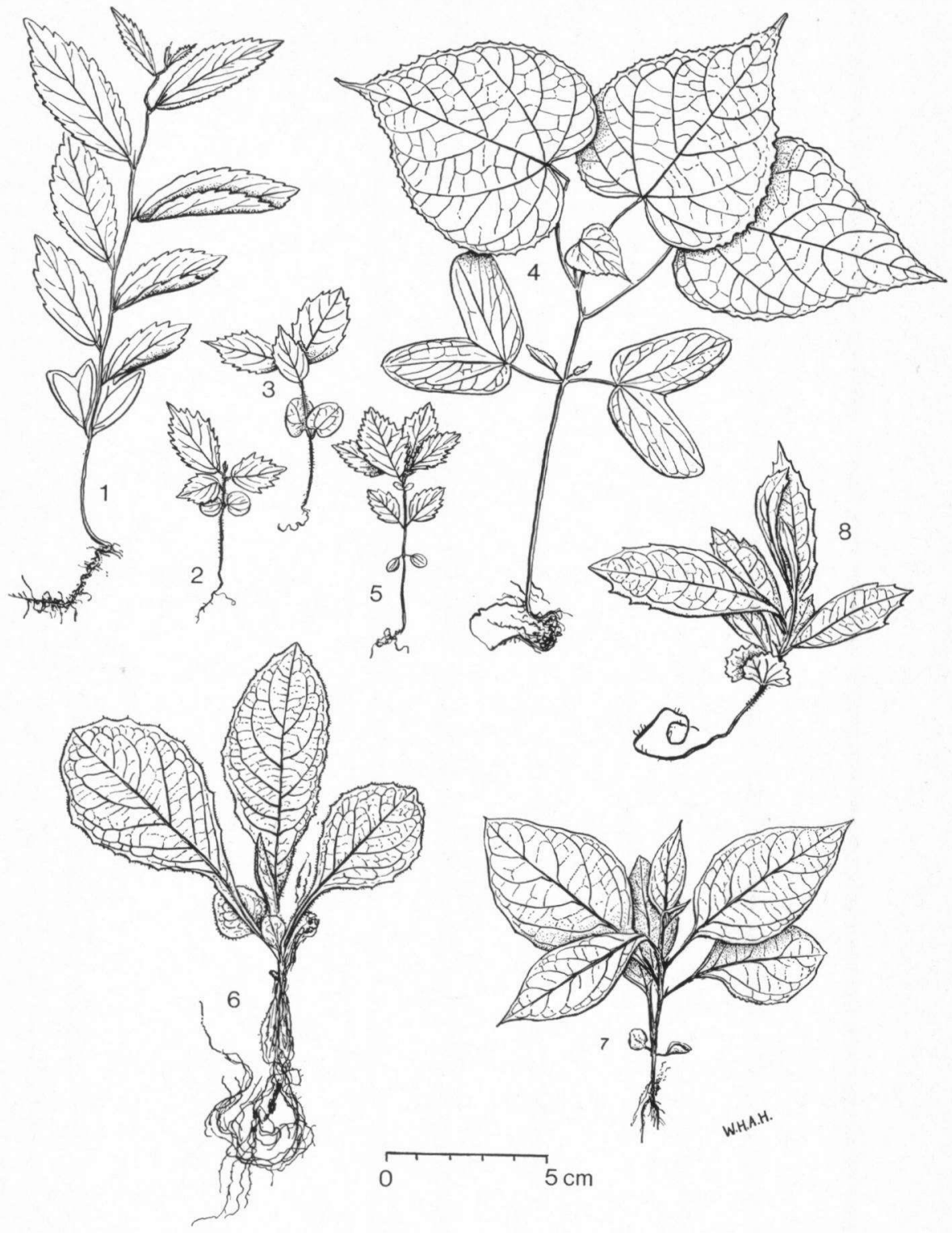

Figs. 1-8. Figures of seedlings: 1 Celtis iguanaea; 2 Luehea divaricata; 3 Luehea candicans; 4 Buettneria catalpifolia; 5 Lamanonia speciosa; 6 Lobelia hassleri; 7 Celosia grandifolia; 8 Patagonula americana. 
folding of a new leaf into a pair of earshaped pseudostipules as has been conserved in the flowering specimen where they are $1 \frac{1}{2}-2 \mathrm{~cm}$ long and half as wide.

4. Aroujia sericofera is rather common in Paraná, but the seeds we used originate from the planalto in Santa Catarina. A fruiting shoot was sent to the Instituto de Biologia in Curitiba for identification by a veterinarian as the species had been eaten by cattle on the campo and caused serious intoxication. In this context it may be important to note that already the first pair of ovate leaves of the seedling has the truncate base and whitishfarinaceous lower leaf surface which distinguish the species from almost any other in the country.

6. At mature age Patagonula americana is a lofty tree with deep green foliage crowded at the tips of numerous short twigs. In the southern spring the tree covers itself with a veil of small creamy sweet-scented flowers and towards the end of the year the small nuts come whirling down, borne by the enlarged 5-winged straw-coloured calices. The crowded sun-leaves and their twigs are almost glabrous, but already in the forest saplings with more pointed leaves with long hairs on petiole and underside of midrib and regularly distributed along hirsute shoots proved to belong to the same species. This is confirmed now by the seedlings (fig. 8) in which even the hypocotyl and the petioles of the ciliate cotyledons are covered by slender hairs $1 \mathrm{~mm}$ long. Gradually the hairs on the shoots stiffen and increase in length to 3 or $4 \mathrm{~mm}$ and half a meter high plants already resemble in every respect the saplings encountered in the shady forest.

7. In Lobelia hassleri the seedling starts to produce a rosette of broad leaves rather different from the later formed cauline leaves ( fig. 6 ). The species is annual, but field studies are necessary to confirm whether it is a true rosulate hemicryptophyte surviving the soft winter in the rosette state.

10. Lamanonia speciosa is a tree with digitate 5-foliolate leaves. Only the ultimate leaf pair of flowering twigs may be reduced to 3 leaflets, but the seedling (fig. 5) starts to produce small simple leaves. The coarsely serrate margin and the foliaceous stipules, however, characterize plants with only the first leaf pairs already as Cunoniaceous. Later there appear compound 3-foliolate and then 5-foliolate leaves. In the greenhouse the species grows very well and as it flowers at a relatively young age and resists nocturnal frost it may be worthwhile to introduce it into gardens in mediterranean countries.

15. Seeds of Tibouchina sellowiana could be taken from a named tree on private ground of the Hatschbach family. The dust-like seeds develop into minute seedlings with circular cotyledons of $1 \frac{1}{2} \mathrm{~mm}$ on equally long petioles. The first pair of leaves is twice this size and under a lens shows 3 costae and slender white hairs, which also spring from the stem internode. Subsequent leaves gradually gain their typical form and the hairs strengthen to setae and assume their definite location and orientation. Identification of young plants in the field, however, will not be possible until it is known from flowering trees which related species are present in the area. 
Fig. 9. Enlarged basal part of abnormal seedling of Aristolochia macroura.

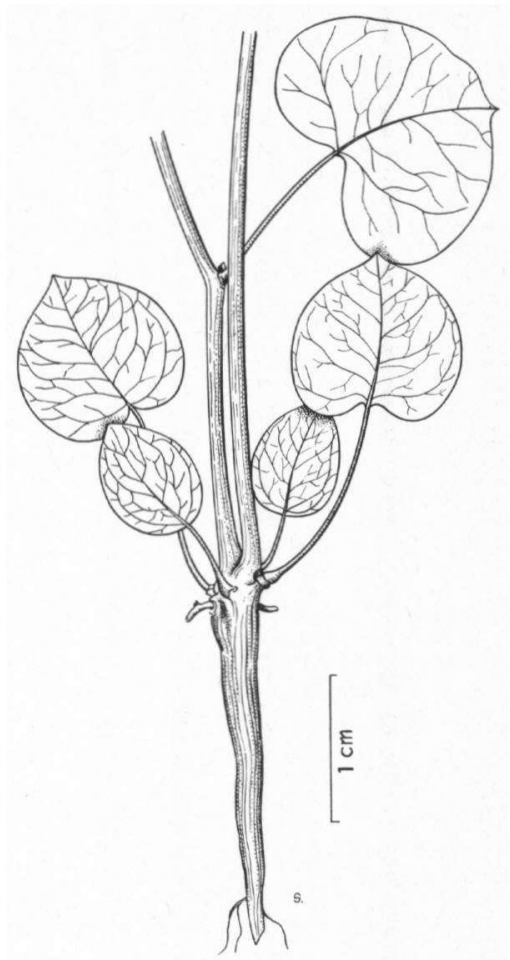

16. Mollinedia blumenavii starts with a ca. $4 \mathrm{~cm}$ long hypocotyl with 2 broadly elliptic apically rounded cotyledons about $2 \mathrm{~cm}$ long of the same texture as the following leaves. These have almost their normal shape from the first pair on and are shallowly denticulate in the upper half.

17. Rapanea ferruginea has almost circular cotyledons $8 \mathrm{~mm}$ in diameter, abruptly contracted into a $1 \mathrm{~mm}$ long, flattened petiole. In other respects, like surface texture of upper and lower side, dark punctate glands, and lateral veins ending in minute marginal teeth, they perfectly resemble the young leaves which after the first few get their normal lanceolate shape. Only afterwards tougher leaves with entire margins are produced.

18. Phytolacca dioica seeds were collected in the yard of the old Fazenda Reserva from a magnificent female tree out of a group of 3 which according to the inhabitants had been grown from local wild seed. In the greenhouse the yearlings already demonstrate clearly the characteristic enlargement of the trunk base.

25. Buettneria catalpifolia is a liana with prickly fruits, each with 5 heavy seeds. These develop into remarkably robust seedlings as fig. 4 shows. Another unusual phenomenon is that branching starts from the axils of the cotyledons. The first leaves have the typical shape, but the margin is denticulate whereas on older plants the leaves have an entire margin.

26. Clavija integrifolia is the southernmost species of a dioecious genus of 
dwarf trees from the understory of tropical humid forest. Near the tropic of Cancer it usually does not grow taller than $1 \frac{1}{2} \mathrm{~m}$ and often remains unbranched with one tuft of large leaves at the top of the stem. The dried seedling had already shed its cotyledons borne on a $5 \mathrm{~cm}$ long, dark purple hypocotyl, but the first 3 leaves show already the tufting habit, the 3 internodes together measuring only $4 \mathrm{~mm}$. The first 2 leaves are circular $(2 \mathrm{~cm}$ diameter) on a $1 \mathrm{~mm}$ long petiole, but have the venation pattern and cartilaginous margin found in the leaves of most species of the genus. The third leaf is obovate and contracted towards the base into a distinct dark purple petiole.

28, 29. Luehea divaricata when in flower or fruit can be distinguished at a distance from its relatives $L$. candicans and $L$. conwentzii, the latter recently discovered by Mr. Hatschbach in Paraná in the Serra do Mar. The vegetative shoots, however, of the first two species are difficult to separate and as fig. 2 and 3 of no. 28 and 29 respectively show, the seedlings are also very similar.

The name $L$. candicans Mart. appears to be the correct but overlooked name instead of the well-known and illustrative name $L$. uniflora St. Hil.

30. Celtis iguanaea has a seedling with large cotyledons (fig. 1). Already the first leaves have the typical shape and bear in their axil a short green spine. In the forest the development and persistence of the spines was found to be very variable within one individual.

31. Hybanthus communis was without much difficulty identified with the older literature both from the dried parent plant and from fresh material in the greenhouse, but the more recent treatment of the Argentinian species of Hybanthus (SPARRE 1950) made us doubt the real value of specific differences. All our plants have more or less violet petals with a yellow spot on the claw of the labellum, as Sparre states for $H$. bicolor, whereas the petals of $H$. communis should be white or yellowish. Besides, the shape and venation of the labellum of fresh flowers do not agree well with any of the rather crude sketches of Sparre. Whereas Schulze (1936) omitted any indication of petal-colours, EICHLER (1871) already described $H$.communis as having a labellum varying from violet with a yellow claw to whitish with only a violet spot on either side of the claw insertion. All authors agree that many characters in the group of species under discussion are markedly variable. For the parent plant in the field colours were recorded in the Munsell notation: lateral petals $2 \frac{1}{2} \mathrm{P} 7 / 6$, plate of labellum $2 \frac{1}{2} \mathrm{P} 8 / 4$, paler towards margin, claw $10 \mathrm{Y} 8 / 8$.

In the greenhouse individual flowers were at least as deeply coloured or much paler, but as they were almost past flowering when this paper was prepared, observations about change of colour during the short anthesis must wait until next year. Meanwhile a plea to collectors seems appropriate to provide detailed field records for Hybanthus species and the authors will gratefully receive dried specimens and seed samples for study. 


\section{SUMÁRIO}

Para 31 espécies de Angiospermas coletadas no Sul do Brasil o número de cromossomos foi determinado. Dessas espécies 7 foram investigadas anteriormente; os outros números são novos, 11 representando primeiras contagens do gênero e um também duma família. Seguem consideraçôes citológicas e morfológicas sôbre parte das espécies.

\section{REFERENCES}

Bezbaruah, H. P. (1963): Induced tetraploidy in Asclepias curassavica L. Curr. Sci. 32: 376. Böcher, T. W., J. P. HJerting \& K. RaHn (1963): Botanical studies in the Atuel Valley Area, Mendoza Province, Argentina, Part I. Dansk Bot. Ark. 22: 1-15.

BorgmanN, E. (1964): Anteil der Polyploiden in der Flora des Bismarckgebirges von Ostneuguinea. Zeitschr. Bot. 52: 118-172.

Covas, G. (1949): Estudios cariológicos en Antófitas III. Darwiniana 9: 156-162.

- \& J. H. Hunziker (1954): Estudios cariológicos en Antófitas IV. Rev. Inv. Agron. Buenos Aires 8: 249-253.

- \& B. Schnack (1946): Número de cromosomas en Antófitas de la region de Cuyo (Republica Argentina). Rev. Argent. Agron. 13: 153-166.

- \& -(1947): Estudios cariológicos en Antófitas II. Rev. Argent. Agron. 14: 224-231.

Diers, L. (1961): Der Anteil an Polyploiden in den Vegetationsgürteln der Westkordillere Perus. Zeitschr. Bot. 49: 437-488.

EICHLER, A. G. (1871): Violaceae in Flora Brasiliensis 13 (1): 361-370.

GADELlA, T. W. J. \& E. KLIPHUIS (1964): Chromosome numbers of some flowering plants collected in Surinam. Acta Bot. Neerl. 13: 432-433.

GotTSCHalK, W. (1954): Die Chromosomen und Struktur der Solanaceen unter Berücksichtigung phylogenetischer Fragenstellungen. Chromosoma 6: 539-626.

GraHAM, S. A. (1966): In IOPB chromosome number reports VI. Taxon 15: 117-128.

HARVEY, M. J. (1966): In IOPB chromosome number reports VII. Taxon 15: 155-163.

Heiser, C. B. (1963): Numeración cromosomica de plantas ecuatorianos. Cien. y. Natur. 6: 2-6.

HuYNH, K. L. (1965): Contribution à l'étude caryologique et embryologique des Phanérogames de Perou. Denkschr. Schweiz. Nat. Ges. 85: 1-178.

LewIs, W. H. (1961): Chromosome numbers for four North American Asclepias. Southwest. Nat. 6: 46-47.

MANGENOT, S. \& G. MANGENOT (1962): Enquête sur les nombres chromosomiques dans une collection d'espèces tropicales. Rev. Cyt. Biol. Végét. 25 : 411-447.

RAHN, K. (1960): Danish scientific investigations in the Argentine under the auspices of the Fundación Williams, Buenos Aires. Chromosome numbers in some South American Angiosperms. Bot. Tidssk. 56: 117-127.

Schnack, B. \& G. Covas (1947): Estudios cariológicos en Antófitas. Haumania 1: 32-41.

Schulze, G. K. (1936): Morphologisch-systematische Studien über die Gattung Hybanthus. Bot. Jahrb. 67: 437-492.

SHETTY, E. (1967): In IOPB chromosome number reports XIV. Taxon 16: 552-571.

ShibatA, K. (1962): Estudios citológicos de plantas colombianas silvestres y cultivadas. Jour. Agr. Sci. Tokyo Daigaku 8: 49-62.

SkovsTed, A. (1941): Chromosome numbers in the Malvaceae II. C. r. Trav. Labor. Carlsberg 23: 195-242.

SPARRE, B. (1950): Estudios sobre las Violaceas Argentinas. Lilloa 23: 515-574.

Sugiura, T. (1936): Studies on the chromosome number in higher plants, with special reference to cytokinesis I. Cytologia 7: 544-595.

Tschischow, N. T. DE (1956): Número de cromosomas de algunas plantas chilenas. Bol. Soc. Biol. Concepción (Chile) 31: 145-147. 